This article was downloaded by: [Monash University Library]

On: 11 April 2015, At: 17:29

Publisher: Routledge

Informa Ltd Registered in England and Wales Registered Number: 1072954

Registered office: Mortimer House, 37-41 Mortimer Street, London W1T

3J H, UK

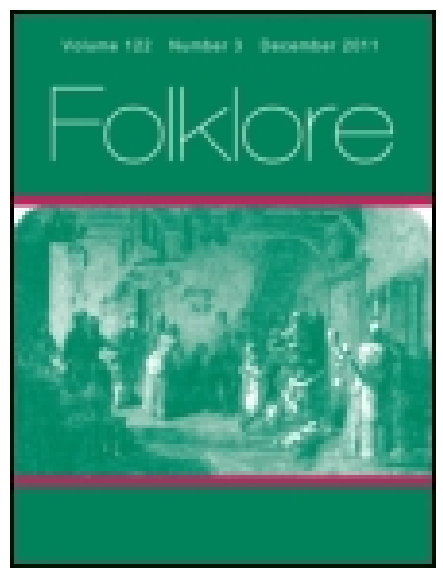

\title{
Folklore
}

Publication details, including instructions for authors and subscription information:

http:// www. tandfonline.com/loi/ rfol20

\section{Korean Beliefs.}

\author{
J as S. Gale a \\ ${ }^{a}$ Wönsan , Korea \\ Published online: 14 Feb 2012.
}

To cite this article: J as S. Gale (1900) Korean Beliefs., Folklore, 11:3, 325-332, DOI: 10.1080/ 0015587X. 1900.9719957

To link to this article: http:// dx. doi. org/ 10.1080/0015587X.1900.9719957

\section{PLEASE SCROLL DOWN FOR ARTICLE}

Taylor \& Francis makes every effort to ensure the accuracy of all the information (the "Content") contained in the publications on our platform. However, Taylor \& Francis, our agents, and our licensors make no representations or warranties whatsoever as to the accuracy, completeness, or suitability for any purpose of the Content. Any opinions and views expressed in this publication are the opinions and views of the authors, and are not the views of or endorsed by Taylor \& Francis. The accuracy of the Content should not be relied upon and should be independently verified with primary sources of information. Taylor and Francis shall not be liable for any losses, actions, claims, proceedings, demands, costs, expenses, damages, and other liabilities whatsoever or howsoever caused arising directly or indirectly in connection with, in relation to or arising out of the use of the Content.

This article may be used for research, teaching, and private study purposes. Any substantial or systematic reproduction, redistribution, reselling, loan, sub-licensing, systematic supply, or distribution in any form to anyone is 
expressly forbidden. Terms $\&$ Conditions of access and use can be found at http://www.tandfonline.com/page/terms-and-conditions 


\section{MISCELLANEA.}

\section{Korean Beliefs.}

Collected by JAS. S. GaLE, (Canadian) Presbyterian Missionary, eleven years in Korea, author of Korean-English Dictionary (4to, I, I60 pp., printed in Yokohama, 1897).

Collectivg items of folklore in a country like Korea is by no means easy. - If I make inquiries of natives who are strangers to me, immediately their suspicions are aroused, and they will not answer more than to say that such a thing does not exist. To inquire for even the number of houses in a village, or what the land produces, much tact is needed, or you create bad feeling at once. The only way I know of is to keep one's ears open when natives are talking to one another, for much will be suggested by such a conversation, and it will often give a clue to questions that you can have honestly and correctly answered by your own particular friends. Customs I find to be, like language, a possession of which the owner is unconscious. For example: a Korean says something, and you ask him to repeat it. He is not able to repeat it exactly, for he is conscious only of the thought that was in his mind, not of the language used, so he will answer by expressing the thought more definitely in some other form, but as for an exact repetition, it will not be forthcoming. So with their customs, they follow them out in the same unconscious manner. Rouse them suddenly and ask them about the matter, and the likelihood is they will deny that such a thing exists at all, and yet they may be absolutely free from any dishonesty in the matter. We are unconscious of the air, for it exists everywhere. Custom is everywhere. The administration of justice is largely a matter of custom. The transfer of land is by custom only and not a matter of law. Marriage too is but custom. The government takes no cognizance of it. The Farthest East is wrapped up in custom, and the native is in many cases the last man to be aware of its existence. 
Notes on Hananrs, ${ }^{2}$ (The Great One, The Orie. God ?) the Korean Great Spirit.-In Korea Hana means one, and Nim is Lord, Master, or Chief, so that the name literally translated means The Ruling One, The Honourable One, The Great One, The One.

He (Hananim) rewards the good (soon) with blessing (pok), and the evil $(a k)$ with punishment (wha). This has no reference to judgment or a future life, but is simply confined to this world.

Here is a snatch from the song of a market minstrel known to all Koreans: "Pap chal mek-ki-nan, Ha-na-nim tok; Ot chao ip-ki-nan ch'o-kwon-eui tok." (Feeding us well is by favour of Hananim; Clothing us well is by favour of wife). This illustrates the idea, common to all Korea, that Hananim provides the rice.

A little pony boy once said, as I was riding his pony, "Hananim knows I have no coat, and so is letting the sun shine to warm me to-day." He had been bowing to the trees and expectorating before the hill shrines most devoutly, so I said, "Why do not you bow and thank Hananim then, since he is so good to you, instead of bowing to the trees?" But," says he, "Hananim is such a long way off; I can't see him, and so I worship the trees instead."

When a Korean sees a wrong done, one of his common sayings is, "Hanali-mu-sim ha-nyaf" (Is Hananim indifferent to such?) He means that Hananim will certainly punish such injustice.

Another expression commonly heard is "Ka-ma-asin Ha-nanim-i pi chu-sin-ta" (Gracious Hananim gives the rain).

Koreans are given to strong language rather than to heavy blows, so a war of words is of frequent occurrence. This is one of the common expressions used at such a time: "Ch'un ang ipeul nom" (A villain who will be punished by Ch'un, or Hananim). Ch'un is the Chinese name for Hananim.

The king offers sacrifice to Hananim for rain (Kl-th-che), using raw food, bathing, and performing other ceremonial cleansing before taking part.

When it lightens and thunders, Koreans say, "Hananim-i o um-ha-si-ta" (Hananim is stern, or awful, or dreadful); and they lay their pipes aside and sit reverently. Again, I hear an old saying that has come down from dim antiquity, "Hananim-i"

If all native transliterations the vowels have the French sound. 
chi-kong-mu-sa ha-ta." (Hananim is eminently just and wholly impartial.)

As regards all spirits (shin) he is the One Great One.

His dwelling-place is above (Ue ke-si-ta $=\mathrm{He}$ dwells above), wherever that may mean, and in Hanal (Heaven), of which he is in possession. No mention is made of his beginning or end. $\mathrm{He}$ never marries, has no son; but a dual union seems to exist between him and the earth $(D a)$, by which all life has come into being.

Hananim is creator of all details; the earth in rough form seems to have been developed by a kind of evolution, or of itself.

No reference is made to Hananim regarding a future life.

When flowers are seen to bloom and the earth to look green and beautiful, they say it is brought about by the (Cho-wha-ong) Ancient Creator-Hananim.

If Hananim desires to kill, he kills; if to save, he saves. When sácrifice has been made to all of the spirits and proves of no avail, the last cry is "Hananim sal-yo chu-so-so" (Save us, Hananim !)

"When Hananim gives rain and dew to the trees, he never forgets the little branches at the side."-A Korean saying.

Hananim mu-so-pul-leung ha-si-ta. (There is nothing that Hananim cannot do)-omnipotent.

Ha-na-nim-eui nun-i su-re pak-hoi tol teut hath-ta. (Hananim's eyes roll everywhere like cart wheels.)

Krwi-sin-to Ha-na-nim-eul mu-sa-wö hau-ta. (The devils, too, fear Hananim.)

These are a few of the more common sayings regarding Hananim. They are all of ancient origin, and as far as is known have no connection with any ancient Christian source.

MOUNTAINS. - Giants and Mountains. - Korea has since ancient times been noted for its sages (Myöngin), its giants (Chang-su), and its dragon-horses (Yong-ma). When a giant appears, his dragonhorse is said also to come forth ready for him. The giant remains quiescent in a cave or under a rock until his country is in danger, and then he comes forth clad in armour, his horse also springing from the mountain. Such tales are common in all ancient Korean story-books (Ko-tam-ch'aik). The giant has power over wind and rain (Pung-un cho-wha). So even to-day the ignorant country people rest assured that when the time comes for the giant to arise from the mountain, all Westerners will have to fly or perish. 
In the Japanese war of three hundred years ago it is said that 500 trained swordsmen were on their way to the capital of Korea. The flash of their swords alone was enough to kill, so it looked as though the whole nation might perish. But just as they landed near Fusan, there came forth from a mountain spur in front, the Old Man on the Green Bull (Ch'ung-u No-in), who had been born from the mountain to save his country. The Japanese pursued, knowing that he was an evil omen, but at first failed to overtake [him], until at last, instead of their capturing him, he entrapped them in a mountain gorge and there slaughtered them all.

Mountain Travel.-Last spring on my way to Seoul, when some $15^{\circ}$ miles from here [Wönsan], I passed a magnificent mountain called the "crying fortress" (U-nan-sung). In speaking of it, the innkeeper told me that King Kung-ye had been defeated there in [9I8 A.D.], and that since then no one could ascend it who had not first fasted from meat and other strong food. ' He told me that the bowls and spoons of Kung-ye were still there.' In order see what answer he would make, I suggested his bringing some away, and that I would buy them. His reply was, anyone doing such a thing would be struck by the God of Thunder and killed at once.

Mountain Spirits.-A hunter I chanced to meet in the mountains a month or so ago, told me that he did all of his hunting at night. "But there are so many tigers; are you not afraid?" I. asked. "No," said he; "I am a retainer of the mountain-spirit (San Yung-nim), and so am safe;" or, "I wait attendance on the mountain-spirit, and so have no cause for fear.". His idea was that the spirit of the mountain controlled tigers and all other animals within its range. In many of the hill-shrines we find pictures of a man riding upon a tiger. It is really the mountainspirit so represented, the tiger being the attendant.

Every village offers sacrifice to the mountain-spirit (San-lung). On an appointed day, after fasting and meditation, sacrificial officers are chosen and a beef slaughtered, and so offered with vegetable food to the spirit. When the sacrifice has been performed according to the spirit's liking, even the dogs of the village are safe from tigers and other wild beasts of the mountain. Tigers are called the dogs of the mountain-spirit.

At every hill pass there is on the side of the road a shrine to the spirit of the mountain. Prayers are offered before the shrine, 
food, live chickens, money, stones, rags, \&c., and passers usually bow and expectorate. On the sacred, or "shrine-tree" (tang na$m u$ ), hang rags, that are meant as charms against evil (ăk$m a k-i)$, while stones as offerings are heaped up beneath. Sometimes small images, in metal, of pigs, rats, elephants, \&c., stand before the picture of the spirit.

Here is one of the prayers, in fact the one common petition, offered to the mountain spirit: "Kil so-e sö-nang-nim, kil-a-rai sö-nang-nim, t'oi" (expectorating) "nip-eu-sin tok to man-man ha-go-ni-wa să-ro să tok-eul nip-ö-chi-i-ta :" i.e. "Spirit of the road, spirit beneath the road, phew!" (giving a spit), "though your favours of the past have been unbounded, grant us some new favours for the future."

Beliefs about Mountains.-(These ideas are common to all Korea.) Mountains are all personified in Korea. They are dragons usually, and according to their formation, graves situated on them are propitious or unpropitious. It never does to build ' a house upon a moving (nă-ryong) or flying dragon (săng-ryong). If the personal influences of a hill-site be too strong, there will be many goblins, and the house will come to destruction.

On May I7th, I899, I purchased a house-site on a hill within the walls of Seoul, and the people living below the hill told me that it was called the "Cow-feeding-her-young" mountain (wa-zthyung). This is a propitious formation, and people are said to live long on it and prosper, so that they tell me I have a fair field for my future when I move up to Seoul.

There is always associated in the native's mind the idea of guardianship with the mountains. Seoul, the capital, has to its north its guardian mountain $S a m-k a k-s a n=$ the three-horned mountain. Shortly after building the former palace (from which the king escaped to the Russian Legation in February, 1896) it was found that there was a hostile mountain (kwan-ak-san) to the south, twenty miles distant, that set fire to the palace. Geomancers succeeded in protecting the dynasty against this mountain by placing two stone lions or fire-eaters $(h \bar{a}$-ta) before the palace gates. These stone figures still stand to-day. Former capitals have always had 'their guardian mountains (chu-san). We find traces of this in Korea long antedating the Christian era. Graves too must have their guardian peaks (chu-pong) or the family will not prosper. A common saying in geomancy, "Dragons do not 
see stones, men do not see dust (in the air), dogs do not see snow, tigers do not see paper."

People are born according to the formation of the hills on which their ancestors' graves are situated. A craggy geomantic formation brings forth warriors-a smooth, well-rounded formation brings forth scholars-a pointed formation brings forth writersan opposing formation brings forth robbers-jade-peaks bring forth beautiful women. Of course all of this must be viewed and tested by a geomancer (chi-kwan), to know what forms are destined to appear.

Mr. Sin-Ki-Sun, the present prime minister of Korea, remarked recently that Korea could never be independent, because she had so many mountains. "Mountains," said he, "depending as they do on each other, denote dependence." Mountains are said to have their pot of silver or pot of gold concealed, and sacrifice is offered diligently to obtain a knowledge of their whereabouts. The mountain spirit, in answer to prayer and sacrifice, makes known in a dream the place where the pot is buried. This may be explained, however, by the fact that during the invasion of the Japanese, three hundred years ago, much money was buried to prevent its being carried off by the invaders, and this being discovered from time to time, may have given rise to the superstition that each hill has its treasury of gold and silver.

I have never been able to fully understand just what the Korean means by currents, or veins of influence, that he invariably connects with the mountains. On the proper circulation of these influences all prosperity depends. April 27 th, 1899, I arrived in a town some 117 miles from Wonsan and 60 miles from Seoul. I saw in the neighbourhood many huge flat stones placed on three smaller ones that were standing on edge. I crossed the fields to one of these, and found it large enough to dance a quadrille on. I had no measuring line, but stepping it, found the stone to be in the neighbourhood of 18 feet square by 2 feet thick. It was raised from the ground some 3 feet, and the propping stones underneath occupied a space of some 8 feet square. They are called $K o i-i n-t o l=$ propped up stone. On inquiry as to their meaning, I was told that the Japanese, three hundred years ago, discovered that this district in Korea had produced many noted warriors and generals, due of course to the current influence of the mountains. Their object now' was to cut off 
these influences as soon as possible. This they accomplished by placing these huge propped-up stones on the back of the current. Another story, giving the same reason, attributes it to the Manchus of a hundred years later. And I am inclined to believe the latter story. In the first place, the stones are too great for the Japanese to handle; in the second place, the Japanese have never paid much attention to mountain influences. Again, the inborn hatred of the Korean for the Japanese would incline him to shift the odium for such a miserable deed from the Chinese to the Japanese. There are several hundred of these monsters in Kangwön province, so I am told. I myself have seen twenty and more.

I asked the old inn-keeper why he did not roll them over, set the current free, and get back the influence, but he said: "Alas ! it is too late." Koreans have a peculiar fatalism in their views of mountain influence. They feel that to disturb the regular course of fate would be worse for them than losing the influence.

IsLANDS. - There is a peculiar superstition, common to all Korea, with regard to a supposed island in the Yellow Sea, called $\mathrm{Nam}$ Chosen (South Korea). They attribute to this place much of the supernatural, and yet people come from it, they say, to trade at Mok-p'o, a port recently opened to foreigners, in Chulla province (S.W. Korea). There is no such place, and yet the story of it is much more common to the natives than that of any real island in the vicinity.

LAKE-SPIRITS AND DRAGONS.-Usually there is no spirit in a pool apart from those who may have fallen in and been drowned in it. Immediately on such occurrence, the spirit of the dead becomes the spirit of the pool, imprisoned, in fact, and cannot leave until some one else drowns and takes its place. Also those who die by tigers become tiger-spirits, and are so possessed until the tiger devours some one else, and so lets the spirit of the first victim free.

In lakes there are dragons (Yong), and monsters less powerful than dragons, called Kang.ch'ulli. Dragons change from pool to pool, or "go up" (ol-la ka-ta), as the native says. I have seen one of the most famous pools of Korea, situated some sixty miles north of Seoul, near Song-do, and it was dark, and deep, and silent; though only some thirty feet wide, it was beyond the eye to fathom, though the water was exceedingly clear. These dragons 
are spoken of as white (päk yong), black (heuk yong), yellow (whang yong), and blue (ch'ung yong).

The serpent is almost synonymous with the dragon. Fish, too, are associated with the same, for the carp may in time become the fish-dragon ( $\ddot{o}$ yong $)$. It is dangerous for fishermen to venture too near a dragon-lake, as the snake with a sudden sweep of the tail may hurl them into its depths.

All flesh cannot arrive at the dragon-stage. - A snake when it spends a thousand years in the mountains and a thousand years in the water, "following closely the doctrine" (to-lak-ta)-(just what this consists in, no one can tell me, but the saying exists; they frequently use the same in reference to disciples of Confucius) -eventually becomes a dragon.

As far as I can understand, water-spouts seen at sea are taken for dragons, and are the source of most dragon-beliefs.

Wells, too, have their dragons, and rice is thrown in to propitiate them on special occasions, as on. the $15^{\text {th }}$ of the Ist moon, or when a child is born. Here, also, as in a lake, if one is drowned the spirit of the dead takes possession of the well.

Rivers and Streams. - There are spirits, too, about rivers, that take various shapes, commonly that of a woman washing clothes in the moonlight. Sometimes it catches those who fish and drags them under deep water. Sacrifice is offered and food is thrown into the river to propitiate the spirit.

A Boatman's Prayer: "Mul-a-ssi kin-tă so-nang-nim' hang-sun chal hage-hayö chu-so-so." (Woman of the waters and prince of serpents, give us a favourable voyage.)

Once, in a six-days' voyage by junk along the north shore of the Yellow Sea, in the year 1889 , we were overtaken by rough weather, when immediately the sailors left caring for the junk and prepared a sacrifice of rice and fish, which, after prayer, they poured overboard in order to propitiate the sea-spirit.

Wönsan, Korea, June 29th, I899.

Jas. S. Gale. 